\title{
Penetapan Margin Dalam Pembiayaan Murabahah
}

Oleh:

\author{
Abdul Rachman \\ Erik Pratama
}

Sekolah Tinggi Ekonomi Syariah (STES) Islamic Village
Jln Raya Islamic Kelapa Dua Tangerang 15810, Indonesia

\begin{abstract}
Abstrak: Penelitian ini bertujuan untuk mengetahui metode penentuan margin yang sesuai dengan syari'ah, mengetahui metode penentuan margin dalam pembiayaan murabahah pada PT. Bank Pembiayaan Rakyak Syariah (BPRS) Berkah Ramadhan - Tangerang, dan apakah metode penentuan margin dalam pembiayaan murabahah pada PT. Bank Pembiayaan Rakyak Syariah (BPRS) Berkah Ramadhan - Tangerang telah patuh terhadap kesesuaian syari'ah. Objek penelitian dalam penelitian ini adalah PT. Bank Pembiayaan Rakyak Syariah (BPRS) Berkah Ramadhan - Tangerang. Metode penelitian yang digunakan oleh peneliti dalam penelitian ini adalah analisis deskriptif kualitatif. Kesimpulan penelitian ini adalah penentuan margin akad murabahah yang syar'i adalah penentuan margin yang tidak melanggar nilai-nilai keadilan dan tidak eksploitatif, penentuan margin akad murabahah PT. Bank Pembiayaan Rakyak Syariah (BPRS) Berkah Ramadhan - Tangerang adalah dengan metode mark-up pricing dan dengan pertimbangan Direct/Indirect Competitors Market Rate (ICMR/DCMR) dengan rata-rata besaran margin 1,5\% - 2\% / bulan.
\end{abstract}

Kata Kunci: Metode Penentuan Margin, Murabahah, BPRS.

\section{Pendahuluan}

Indonesia sebagai Negara yang mayoritas penduduknya beragama Islam, telah lama mendambakan kehadiran sistem lembaga keuangan yang sesusai tuntutan kebutuhan tidak sebatas financial namun juga tuntutan moralitasnya. Kemunculannya sistem ekonomi syariah dipandang sebagai suatu alternatif sistem keuangan perekonomian dunia. Sistem dengan karakter utamanya yang bebas bunga ini memperoleh apresiasi dan sambutan dalam masyarakat luas. Kesuksesan tersebut diindikasikan oleh jumlah bank syariah yang semakin banyak tersebar di daerah-daerah di Indonesia, serta semakin banyaknya nasabah dan dana yang dikelola oleh bank syariah. 
Pada saat ini praktik perbankan syraiah dan BPRS dalam menentukan kebijakan harga jual yang diinginkan tidaklah terlepas dari rujukan (benchmark) kepada suku bunga bank konvensional, tingkat pesaing (competitior), dll. Di sisi lain, masih terdapat kritikan-kritikan terhadap beberapa praktik yang dilakukan perbankan syariah dan BPRS selama ini terutama pada jual beli murabahah yang dianggap masih sama dengan kredit pada perbankan konvensiaonal. Hipotesa ini didasarkan pada kenyataan bahwa proses penentuan harga jual murabahah adalah tetap menggunakan metode pembebanan bunga flat rate dan prinsip cost of fund yang merupakan pilar utama dalam perbankan konvensional.

Sebagai sistem alternatif, bank syariah dirancang untuk menyediakan berbagai layanan sistem keuangan dan perbankan kepada masyarakat, dengan memperkenalkan prinsip-prinsip muamalah Islam. Selayaknya bank pada umumnya, Bank Syariah juga menyediakan pilihan sarana investasi dan pembiayaan yang diperlukan masyarakat yang sejalan dengan syariah Islam. Salah satu fungsi utama perbankan syariah adalah mengelola secara efektif dan memberikan suatu nilai kompetitif dalam pembiayaan yang menggambarkan sistem keuangan syariah. Penetapan keuntungan dari harga jual sejumlah tertentu dangan mempertimbangkan keuntungan yang akan diambil, biaya-biaya yang ditanggung termasuk antisipasi timbulnya kemacetan dan jangka waktu pengembalian.

\section{Margin}

Margin menurut Kamus Besar Bahasa Indonesia (2008:850) adalah laba berdasarkan tingkat selisih antara biaya produksi dan harga jual di pasar. Secara tersirat, Karim (2008:113) mendefinisikan margin sebagai keuntungan yang disepakati dari akad murabahah, berikut kutipannya " murabahah akad jual beli barang dengan menyatakan harga perolehan dan keuntungan (margin) yang disepakati oleh penjual dan pembeli".

Penetapan keuntungan dari harga jual sejumlah tertentu dangan mempertimbangkan keuntungan yang akan diambil, biaya-biaya yang ditanggung termasuk antisipasi timbulnya kemacetan dan jangka waktu pengembalian.

Faturrahman Djamil (2012:1) dalam bukunya yang berjudul Penyelesaian Pembiayaan Bermasalah Di Bank Syariah mengatakan bahwa bank melakukan penetapan margin/keuntungan dari harga jual sejumlah tertentu dengan mempertimbangkan keuntungan yang akan diambil, biayabiaya yang ditanggung termasuk antisipasi timbulnya kemacetan dan jangka waktu pengembalian. Hal ini ditunjang oleh undang-undang perbankan UU No. 10 Th. 1998 tentang perubahan undang-undang nomor 7 tahun 1992 tentang perbankan, Pasal 1 No. 13 dan Pasal 6 huruf m, yang berisikan tentang pembiayaan pada perbankan syariah. 
Salah satu metode yang dapat digunakan dalam melakukan penghitungan harga jual pada pembiayaan murabahah dapat dirumuskan sebagai berikut :

Gambar 2.4 : Contoh Perhitungan Harga Jual dalam Mu

\begin{tabular}{|c|c|}
\hline Harga Jual Bank & $\begin{aligned}= & \text { Harga Beli Bank }+ \text { Cost Recovery }+ \text { Keuntungan } \\
& \text { Proyeksi Biaya Operasi }\end{aligned}$ \\
\hline Cost Recovery & Target Volume Pembiayaan \\
\hline Margin dalam Presentase & $=\frac{\text { Cost Recovery + Keuntungan }}{\text { Harga Beli Bank }} \times 100 \%$ \\
\hline
\end{tabular}

\section{Akad Murabahah}

Murabahah adalah jual-beli barang pada dengan tambahan keuntungan yang disepakati. Dalam ba'i murabahah, penjual harus memperhitungkan bahwa harga produk yang ia beli dan menentukan suatu tingkatan keuntungan sebagai tambahannya. Misalnya pedagang eceran membeli komputer dari grosir dengan harga Rp. 10.000.000,- kemudian ia menambahkan keuntungan sebesar Rp. 750.000,- dan ia menjual kepada si pembeli dengan harga Rp. 10.750.000,-. Pada umumnya si pedagang eceran tidak akan memesan dari grosir sebelum ada pesanan dari calon pembeli dan mereka sudah menyepakati tentang lama pembiayaan, besar keuntungan yang akan diambil pedagang eceran, serta besarnya angsuran kalau memang akan dibayar secara angsuran.

Ba'i murabahah dilakukan untuk pembelian secara pemesanan dan biasa disebut sebagai murabahah kepada pemesan pembelian (KPP). Imam Syafi'i dalam Al-um menyebutkan transaksi sejenis ini dengan istilah AlAmru bisy-syira. Harga jual kepada pemesanan adalah harga pokok ditambah margin (perbedaan antara jual dan harga beli suatu komoditi, untuk menyelamatkan perantara dari kerugian) keuntungan yang disepakati. Kesepakatan harga jual dicantumkan dalam akad jual-beli dan tidak dapat berubah menjadi lebih mahal selama berlakunya akad.

\section{Syarat Ba'i Murabahah}

a. Harus digunakan untuk barang-barang yang halal ; barang najis tidak sah diperjual-belikan dan barang bukan larangan negara.

b. Penjual memberitahukan biaya modal kepada nasabah.

c. Kontrak pertama harus sah sesuai dengan rukun yang ditetapkan. 
d. Penjual harus menjelaskan kepada pembeli bila terjadi cacat atas barang sesudah pembelian.

e. Penjual harus menyampaikan semua hal yang berkaitan dengan pembelian, misalnya jika pembelian dilakukan secara hutang.

Daud Vicary Abdullah dan Keon Chee, dalam bukunya menuliskan bahwa murabahah adalah jenis lain dari pembiayaan ongkos-plus. Sebagaimana dengan BBA (bai' bitsaman ajil), anda menentukan rumah, bank membelinya dan kemudian menjualnya kepada anda dengan harga berupa ongkos atau biaya plus margin laba. Aturan dalam murabahah adalah bahwa bank harus mengungkapkan biayanya dan margin labanya. Harga jual kemudian dibayarkan secara penuh atau mengangsur. Sebagai perbandingan, BBA juga penjualan dengan ongkos-plus, tapi pembayarannya selalu dalam bentuk cicilan. Di Asia Tenggara, murabahah umum digunakan dalam pembiayaan modal kerja. Sementara di Timur Tengah, murabahah digunakan untuk modal kerja sebagaimana juga untuk pembiayaan proyek jangka panjang

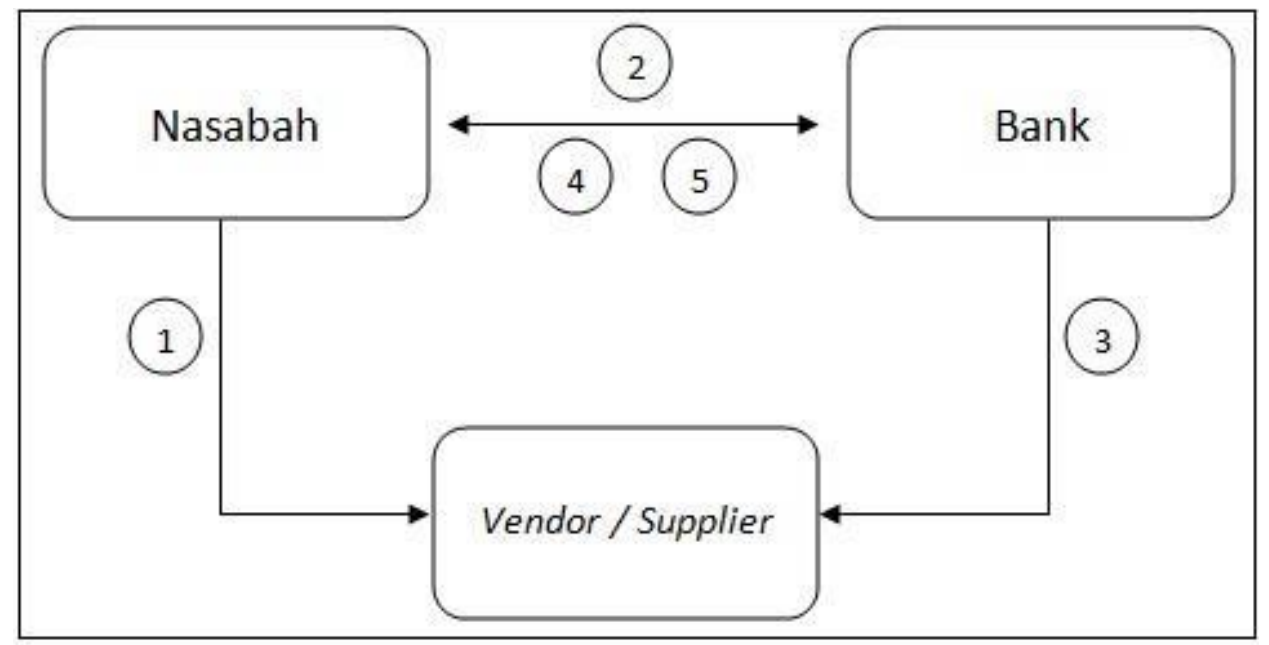

Gambar 2.5 : Contoh Skema Transaksi Murabahah

\section{Teknik Perhitungan}

Teknis perhitungan yang diperlukan PT. BPRS Berkah Ramadhan Tangerang dalam transaksi murabahah antara lain adalah :

1. Perhitungan penentuan Margin Murabahah. Dalam praktik, perbankan, biasanya margin di hitung dengan menggunakan metode anuitas, makin lama jangka waktu maka makin besar margin yang di kenakan pada nasabah. Dalam diskusi ekonomi syariah, pembolehan konsep tersebut dikarenakan konsep anuitas hanya digunakan sebagai dasar perhitungan margin. Setelah margin ditentuka, nilai 
margin tersebut bersifat tetap dan tidak berubah kendatin terjadi keterlambatan pembayaran oleh nasabah.

2. Perhitungan angsuran perbulan dan pendapatan yang diakui. Angsuran perbulan bersifat merata atau tetap sepanjang masa pelunasan. Perhitungan angsuran dapat dilakukan dengan rumus sebagai berikut:

Angsuran perbulan $=$ total piutang - uang muka

Jumlah bulan pelunasan Misalkan dengan mengunakan data murabahah dengan pesanan diatas (total piutang Rp 118 juta, uang muka 10 juta, jangka waktu 24 bulan), maka : Angsuran perbulan $=($ total piutang uang muka) jumlah bulan pelunasan $=(\operatorname{Rp} 118.000 .000-R p 10.000 .000) /$ $24=\operatorname{Rp} 108.000 .000 / 24=\operatorname{Rp} 4.500 .000$,- Untuk mendapatkan hasil yang sama, angsuran perbulan juga dapat dihitung dengan menjumlahkan pokok perbulan dengan margin per bulan.

3. Perhitungan pendapatan margin yang diakui saat jatuh tempo atau pembayaran angsuran. Setiap tanggal jatuh tempo, bank syariah akan mengakui adanya pendapatan margin. Besarnya pendapatan margin yang diakui tergantung pada alternatif pendekatan yang digunakan. Bila bank menggunakaan pendekatan proporsional, maka besarnya margin setiap bulan adalah sama, sedangkan bila menggunakan tabel anuitas, maka margin pada bulan pertama akan lebih besar dibanding dengan bulan kedua dan seterusnya.

Hasil penelitian ini diperoleh dengan teknik wawancara dengan narasumber, sebagai bentuk pencarian data dan dokumentasi langsung dilapangan kemudian dianalisis. Analisis ini sendiri terfokus pada penetapan margin dalam murabahah, yang dikaitkan kepada beberapa unsur atau identifikasi masalah. Agar penelitian ini lebih objektif dan akurat, peneliti mencari informasi melalui wawancara dengan pihak PT. BPRS Berkah Ramadhan Tangerang dan beberapa informan pendukung yaitu nasabah PT. BPRS Berkah Ramadhan Tangerang itu sendiri.

Untuk tahap analisis, yang dilakukan oleh peneliti adalah membuat daftar pertanyaan untuk wawancara, pengumpulan data, dan analisis data yang dilakukan sendiri oleh peneliti. Untuk dapat mengetahui sejauh mana informasi yang diberikan oleh narasumber penelitian, peneliti menggunakan beberapa tahap :

1. Menyusun drafat pertanyaan wawancara berdasarkan unsur-unsur kredibilitas yang akan ditanyakan pada narasumber.

2. Melakukan wawancara dengan PT. BPRS Berkah Ramadhan Tangerang. Selain itu juga peneliti malakukan wawancara dengan para nasabah guna menjadi data pendukung.

3. Melakukan dokumentasi langsung dilapangan untuk melengkapi data-data yang berhubungan dengan penelitian. 
4. Memindahkan data penelitian yang berbentuk daftar dari semua pertanyaan yang diajukan kepada narasumber.

5. Menganalisis data hasil wawancara yang telah dilakukan. Agar pembahasan lebih sistematis dan terarah, maka peneliti membagi ke dalam 3 pembahasan, yaitu :
a. Profil Narasumber
b. Analisis Deskriptif Hasil Penelitian
c. Pembahasan

\section{Pemberian Modal (Pembiayaan) Bagi Nasabah}

PT. Bank Pembiayaan Rakyat Syariah (BPRS) Berkah Ramadhan Tangerang merupakan bagian dari Lembaga Keuangan yang memiliki peran sebagai intermediator antara pihak ekonomi surplus dengan pihak ekonomi defisit yaitu dengan cara menyerap dana dan menyalurkannya kembali dalam bentuk cicilan yang mana dalam lembaga keuangan syariah lebih dikenal dengan istilah pembiayaan.

Menurut Kasmir $(2011,73)$ pembiayaan adalah penyediaan uang atau tagihan yang dapat dipersamakan dengan itu, berdasarkan persetujuan atau kesepakatan pinjam meminjam antara pihak lembaga keuangan dengan pihak lain yang mewajibkan pihak peminjam untuk melunasi hutangnya dalan jangka waktu tertentu dengan disertai bagi hasil dan dijalankan sesuai dengan prinsip syariah.

Adapun tujuan dari pembiayaan berdasarkan prinsip syariah adalah untuk meningkatkan kualitas usaha dalam menunjang produksi dan distribusi barang-barang dan jasa-jasa serta meningkatkan kesejahteraan ekonomi sesuai dengan nilai-nilai Islam.

Penyaluran pembiayaan yang dilakukan oleh Lembaga Keuangan Mikro Syariah kepada Usaha Mikro dan Kecil menggunakan beberapa jenis kategori. Menurut Kasmir (2002, 99-101) pembiayaan memiliki banyak jenis yang terbagi menjadi beberapa kategori, antara lain :

1. Jenis Pembiayaan Dilihat dari Segi Kegunaan

a. Pembiayaan Investasi adalah pembiayaan yang biasanya digunakan untuk perluasan usaha atau membangun proyek/pabrik atau untuk keperluan rehabilitasi.

b. Pembiayaan Modal Kerja adalah pembiayaan yang biasanya digunakan untuk keperluan meningkatkan produksi dalam oprasionalnya.

2. Jenis Pembiayaan Dilihat dari Tujuan

a. Pembiayaan Konsumtif, bertujuan untuk memperoleh barangbarang atau kebutuhan- kebutuhan lainnya guna memenuhi keputusan dalam konsumsi. 
b. Pembiayaan Produktif, bertujuan untuk memungkinkan penerima pembiayaan dapat mencapai tujuannya yang apabila tanpa pembiayaan tersebut tidak mungkin dapat diwujudkan.

c. Pembiayaan Perdagangan, Pembiayaan ini digunakan untuk perdagangan, biasanya digunakan untuk membeli barang dagangan yang pembayarannya diharapkan dari hasil penjualan barang dagangan tersebut.

3. Jenis Pembiayaan Dilihat dari Jangka Waktu

a. Short Term (Pembiayaan Jangka Pendek), yaitu suatu bentuk pembiayaan yang berjangka waktu maksimum 1 (satu) tahun.

b. Intermediate Term (Pembiayaan Jangka Waktu Menengah) adalah suatu bentuk pembiayaan yang berjangka waktu lebih dari satu tahun sampai tiga tahun.

c. Long Term (Pembiayaan Jangka Panjang), yaitu suatu bentuk pembiayaan yang berjangka waktu lebih dari tiga tahun.

d. Demand Loan atau Call Loan adalah suatu bentuk pembiayaan yang setiap waktu dapat diminta kembali.

4. Jenis Pembiayaan Dilihat dari Segi Jaminan

a. Pembiayaan Dengan Jaminan, yaitu pembiayaan yang diberikan dengan suatu jaminan, jaminan tersebut dapat berbentuk barang berwujud atau tidak berwujud atau jaminan orang.

b. Pembiayaan Tanpa Jaminan, yaitu pembiayaan yang diberikan tanpa jaminan barang atau orang tertentu. Pembiayaan ini diberikan dengan melihat prospek usaha dan karakter serta loyalitas atau nama baik calon peminjam selama ini.

\section{Kesimpulan}

Berdasarkan uraian pembahasan di atas dapat disimpulkan bahwa: Penentuan harga jual dan margin akad murabahah yang syar'i adalah penentuan harga jual dan margin yang tidak melanggar nilai-nilai keadilan dan tidak eksploitatif. Kesimpulan peneliti ini dilandaskan oleh kaidahkaidah muamalah, termasuk di dalamnya mekanisme penentuan harga jual dengan akad murabahah, secara ushul fiqh adalah boleh. Hal ini selama tidak melanggar nilai-nilai syari'at mulai dari proses identifikasi produk, pembelian produk, akad, sampai penyelesaian. Dan mekanisme penentuan harga jual terletak pada prosesi akad yang di dalamnya juga harus syar'i dengan tidak melanggar nilai keadilan dan tidak eksploitatif.

Penentuan margin akad murabahah PT. BPRS Berkah ramadhan Tangerang adalah dengan metode mark-up pricing dan dengan pertimbangan Direct/Indirect Competitors Market Rate (ICMR/DCMR) dengan rata-rata besaran margin $18 \%$ per tahun. Penentuan margin ini dilandasi oleh beberapa pertimbangan yaitu beban operasional, kewajiban 
pada pihak kreditor (bank syari'ah), dana sosial, dan pencadangan utang macet.

Penentuan harga jual dan margin akad murabahah PT. BPRS Berkah ramadhan - Tangerang telah syar'i dengan pertimbangan :

a. PT. BPRS Berkah ramadhan - Tangerang telah mengimplementasikan nilai-nilai keadilan dalam proses penentuan harga jual murabahahnya. Hal ini dilandaskan pada asas keadilan antara kepentingan nasabah dan PT. BPRS Berkah Ramadhan, antara penegakan syi'ar ekonomi islam dengan kemampuan operasional PT. BPRS Berkah ramadhan (termasuk kepentingan mencari laba), dan kemampuan PT. BPRS Berkah ramadhan - Tangerang menjabarkan antara market PT. BPRS Berkah ramadhan - Tangerang yang signifikan dengan penentuan margin yang proporsional (tidak terlalu kecil dan tidak terlalu besar).

b. PT. BPRS Berkah ramadhan - Tangerang, dalam proses penentuan margin murabahah, tidak terdapat unsur eksploitasi di dalamnya, terkhusus untuk pihak PT. BPRS Berkah Ramadhan kepada pihak nasabah. Hal ini dikarenakan prinsip kepercayaan yang dibangun oleh pihak PT. BPRS Berkah Ramadhan menjadi karakter utama dalam setiap operasional PT. BPRS Berkah Ramadhan

Tangerang. Kita bisa mendapati PT. BPRS Berkah Ramadhan Tangerang masih bisa bernegosiasi untuk besaran margin murabahah pada saat melakukan akad. Nasabah juga diberi fasilitas untuk membeli sendiri barang yang ingin dibiayakan dengan akad murabahah. Dengan fasilitas wakalah, perwakilan dari pihak keluarga nasabah, untuk membeli barang sesuai dengan spesifikasi permintaan nasabah. 


\title{
Faktor-Faktor Yang Mempengaruhi Pengetahuan Karyawan Tentang Produk- Produk Perbankan Syariah
}

\author{
Oleh: \\ Muklis \\ Eva Nauli Rahma
}

Sekolah Tinggi Ekonomi Syariah (STES) Islamic Village Jln Raya Islamic Village Kelapa Dua Tangerang 15810, Indonesia

\begin{abstract}
Abstrak: Penelitian ini menemukan factor-faktor pengetahuan berpengaruh positif terhadap pengetahuan karyawan tentang produk-produk bank syariah pada PT. Bank BRI Syariah Kantor Cabang Tangerang. Penelitian ini menggunakan metode deskriptif kuantitatif, dengan menggunakan sampel sebanyak 38 responden, pengumpulan data menggunakan angket kuesioner dan dianalisis menggunakan regresi linear berganda, dimana sebelumnya dilakukan uji validitas dan uji reliabilitas terlebih dahulu. Pada uji parsial hasil penelitian ini menunjukan bahwa variabel persepsi karyawan terhadap bank syariah dan latar belakang pengetahuan agama tidak berpengaruh positif pada variabel pengetahuan karyawan tentang produk-produk bank syariah, sedangkan variabel prinsip-prinsip operasional bank syariah dan pelatihan berpengaruh positif dan signifikan terhadap variabel pengetahuan karyawan tentang produkproduk bank syariah. Pada uji simultan variabel-variabel independen secara signifikan mempengaruhi variabel dependen. Kata Kunci: Persepsi Karyawan Terhadap Bank Syariah, PrinsipPrinsip Dasar Operasional Bank Syariah, Latar Belakang Pengetahuan Agama, Pelatihan dan Pengaruh Pengetahuan Karyawan tentang Produk-Produk Perbankan Syariah.
\end{abstract}

\section{Pendahuluan}

Menurut Undang-Undang No. 10 tahun 1998, Bank adalah badan usaha yang menghimpun dana dari masyarakat dalam bentuk simpanan dan menyalurkanya kepada masyarakat dalam bentuk kredit atau bentukbentuk lainnya dalam rangka meningkatkan taraf hidup rakyat banyak. Adanya pengaturan perbankan ditujukan untuk menjaga operasi bank dapat berjalan dengan baik, dan dapat mengoptimalkan fungsi bank sebagai lembaga intermediasiantara pihak yang kelebihan dana dengan pihak yang kekurangan dana yang memungkinkan kegiatan ekonomi dapat terpengaruh secara signifikan. 
Dalam perkembanganya, Bank Syariah tumbuh pesat di Indonesia. Hal ini ditandai dengan semakin banyaknya bank konvensional yang akhirnya mendirikan unit-unit Syariah, ini membuktikan bahwa Bank Syariah memang mempunyai potensi yang tinggi ini juga menunjukan bahwa minat masyarakat untuk menjadi nasabah Bank Syariah tinggi. namun, perbankan Syariah akan semakin tinggi lagi pertumbuhannya apabila masyarakat mempunyai permintaan dan antusias yang tinggi dikarenakan faktor peningkatan pemahaman dan pengetahuan tentang Bank Syariah, disamping faktor penyebab lainya.

Kendati secara prinsip Bank Syariah memiliki beberapa kelebihan, namun dalam realitanya Bank Syariah mengahadapi beberapa tantangan dan kelemahan yang memerlukan pembenahan. Diantaranya yaitu jaringan operasi yang belum luas, institusi pendukung yang belum lengkap dan efektif, efesiensi operasional Bank Syariah yang belum optimal dan masih sedikitnya sumber daya manusia yang memiliki keahlian dalam perbankan Syariah. Dari sisi konsumen, kelemahan lainnya yakni masih terbatansya pemahaman masyarakat mengenai kegiatan usaha jasa keuangan perbankan Syariah dan produk-produk yang ditawarkan.

Keterbatasan ini menyebabkan banyak masyarakat yang memiliki persepsi yang kurang tepat mengenai operasi dan produk Bank Syariah, melihat fenomena tersebut bank dituntut mampu menawarkan produkproduk sesuai dengan kebutuhan dan keinginan nasabah saat ini. Dengan memanfaatkan produk yang ditawarkan, perbankan harus dapat merebut perhatian calon nasabah tidak hanya sekedar memperkenalkan produk sehingga nasabah menggunakanya, namun menjadikan nasabah loyal terhadap bank tersebut.

Pemahaman dan pengetahuan karyawan Bank Syariah dan masyarakat tentang Bank Syariah umumnya, dan produk Bank Syariah khususnya. Dalam memperkenalkan produk kepada nasabah yang sering menjadi pertanyaan adalah apakah karyawan Bank Syariah memiliki pengetahuan dan telah mengikuti pelatihan keuangan Islam dan produkproduk Bank Syariah yang memadai.

Menurut Zaenal (2008) dalam Harun, dkk (2015), para bankir Bank Syariah memiliki pengetahuan yang terbatas tentang keuangan Islam dan produk Bank Syariah sebelum mereka bekerja di Bank tersebut. mereka juga tidak memahami perbedaan antara sistem Bank Syariah dan Bank konvensional. Hal ini didukung oleh hasil penelitian Baba dan Amin (2009) dalam Harun, dkk (2015), bahwa persepsi diantara para bankir yang menunjukan bahwa mereka tidak melihat adanya perbedaan antara Bank Syariah dan Bank konvensional. Dan pemahaman prinsip-prinsip atau konsep-konsep tentang produk-produk Bank Syariah diantara mereka juga minim, oleh karena itu penting bahwa karyawan perbankan Syariah 
memiliki pemahaman yang mendalam dari industri perbankan Syariah sehingga akan memiliki keunggulan kompetetif atas Bank konvensional. Dalam hal ini, pihak berwenang menyarankan untuk menyediakan lebih banyak infrastruktur dan ketentuan untuk memberikan karyawan perbankan Syariah dengan pengetahuan yang cukup untuk memungkinkan mereka dalam melakukan tugas mereka sesuai dengan prinsip Syariah.

Faktor-faktor yang berkontribusi terhadap pengetahuan tentang produk perbankan Syariah adalah pemahaman istilah mendasar dalam perbankan Syariah (Tambiahet al, 2011) dalam Harun, dkk (2015), kelompok umur (Khattak dan Rehman, 2010), tingkat pendidikan (Run \& Lip, 2008) dalam Harun, dkk (2015) dan kewajiban agama (Khan et al.,2008). Faktor-faktor ini memiliki hubungan yang signifikan dengan pengetahuan. Namun demikian apakah masih ada faktor-faktor lain yang memberikan dampak pada pengetahuan produk perbankan Syariah bagi para karyawanya.

\section{Pengetahuan}

Menurut Gloet dan Terziovski (2004), dalam Harun, dkk (2015), definisi dari istilah pengetahuan bervariasi, pengetahuan adalah berbagai gejala yang ditemui dan diperoleh manusia melalui pengamatan akal, pengetahuan muncul ketika seseorang menggunakan akal budinya untuk mengenali benda atau kejadian tertentu yang belum pernah dilihat atau dirasakan sebelumnya. Selain itu, definisi dan penggunaan arti dari pengetahuan yang dapat diartikan sebagai arti dari informasi dimana ia memberikan kontribusi untuk mempengaruhi asumsi pengetahuan yang sebenarnya dapat dikelola dengan cara yang sama seperti orang-orang yang memilikinya, Loughridge (1999) dalam Harun dkk (2015). Di dalam AlQur'an juga telah dijelaskan pada surat Al-Baqarah ayat 30-33. Ayat tersebut menjelaskan bahwa kualifikasi dasar manusia adalah untuk menjadi khalifah di muka bumi ini dengan pengetahuan yang mereka punya yang telah diberikan oleh allah SWT.

\section{Persepsi Karyawan Terhadap Bank Syariah}

Persepsi dapat didefinisikan sebagai suatu proses dengan tindakan menyusun dan menafsirkan kesan indera mereka agar memberi makna dan pemahaman pada lingkungan mereka Robbins (1998:88), dalam Ath-thora (2004). Bagaimana pun, apa yang dipersepsikan seseorang dapat berbeda dari kenyataan yang obyektif. Tidak harus demikian, tetapi sering ada ketidakpastian misalnya, dimungkinkan bahwa persepsi karyawan terhadap Bank Syariah dalam perusahaan memandang perusahaan itu sebagai tempat yang hebat untuk bekerja (kondisi kerja yang menguntungkan, tugas pekerjaan yang menarik, upah yang baik, 
manajemen yang bijaksana dan bertanggung jawab), tetapi seperti kebanyakan kita tahu, sangatlah tidak biasa untuk mendapatkan kesepakatan seperti itu.

\section{Prinsip-Prinsip Dasar Operasional Bank Syariah}

Prinsip adalah suatu pernyataan fundemental atau kebenaran umum maupun individual yang dijadikan oleh seseorang/kelompok sebagai sebuah pedoman untuk berpikir atau bertindak dan seperangkat teori dan ide-ide yang berkaitan dengan pemahamanya (Al-jarbi, 2004) dalam Harun, dkk (2015).

\section{Latar Belakang Agama}

Menurut Nashori dan Mucharam (2002), dalam Rohayati (2014), religiusitas sebagai seberapa jauh pengetahuan, seberapa kokoh keyakinan, seberapa pelaksanaan ibadah dan kaidah dan seberapa dalam penghayatan atas agama yang dianutnya. Bagi seorang muslim, religiusitas dapat diketahui dari seberapa jauh pengetahuan, keyakinan, pelaksanaan dan penghayatan atas agama Islam.

\section{Pelatihan}

Satu organisasi akan dapat bersaing dengan organisasi lain apabila organisasi tersebut memiliki sumber daya manusia yang mempunyai kemampuan dan pengetahuan yang kompetetif. Oleh karena itu, fungsi seorang pemimpin sebagai pencipta, perencana, motivator, komunikator, dan pengawasan.

Dalam mengelola seluruh aset perusahaan, diupayakan untuk dapat semaksimal serta seefisien mungkin, agar mampu memperoleh keuntungan yang menjadi salah satu tujuan dari organisasi. Efisiensi suatu organisasi tergantung dari bagaimana pengembangan anggota organisasi tersebut. Dengan demikian, tujuan organisasi dapat tercapai apabila seluruh karyawan dapat terlatih dengan sempurna. Latihan-latihan yang baik diperlakukan oleh setiap karyawan baru ataupun karyawan lama.

\section{Pengertian Bank Syariah dan Bank Konvensional}

Kata Bank bermakna suatu lembaga keuangan yang berfungsi sebagai perantara keuangan dari dua pihak, yaitu pihak yang berkelebihan dana dan pihak yang kekurangan dana. Kata Syariah dalam versi Bank Syariah Indonesia adalah aturan perjanjian berdasarkan yang dilakukan oleh pihak Bank dan pihak lain untuk penyimpanan dana dan pembiayaan kegiatan usaha dan kegiatan lainya sesuai dengan hukum Islam. Zainuddin (2007: 1) dalam Mandiri (2013:14). 


\section{Produk-Produk Bank Syariah}

Sama seperti halnya dengan bank konvensional, Bank Syariah menawarkan kepada nasabahnya dengan beragam produk perbankan. Hanya saja bedanya dengan bank konvensional adalah dalam hal penentuan harga, baik terhadap harga jual maupun harga belinya. Produkproduk yang ditawarkan sudah tentu sangat islami (Abdullah Thamrin dan Francis Tantri, 2013-2014:215). termasuk dalam memberikan pelayanan kepada nasabahnya diantaranya titipan, tabungan, deposito, jasa, dan peminjaman. Jenis-jenis produk Bank Syariah ditawarkan adalah sebagai berikut:

\section{Produk Dana}

a. Giro Syariah

Pengelola dana masyarakat yang dihimpun bank Syariah dalam bentuk giro dapat menggunakan akad wadiah yadh dhommanah dengan prinsip titipan dan bagi hasil (mudharabah). Giro terbagi dua yaitu:

1) Giro Wadiah Adalah penempatan dana dalam bentuk giro tanpa mendapatkan imbalan, namun bank boleh memberi dalam bentuk bonus tanpa diperjanjikan dengan nasabah.

2) Giro Mudharabah Merupakan penempatan dana dalam bentuk giro dengan hak imbalan sesuai dengan porsi bagi hasil (nisbah) yang diperjanjikan dengan nasabah pada saat pembukaan rekening.

b. Tabungan Syariah. Tabungan merupakan simpanan yang penarikanya hanya dapat dilakukan menurut syarat tertentu yang disepakati, tetapi tidak dapat ditarik dengan cek atau bilyet giro ataupun alat lain. Transaksi tabungan syariah berbeda dengan tabungan biasa karena dana yang ditempatkan diperlakukan sebagai titipan (wadiah), dan dapat pula bebagai hasil (mudharabah).

1) Tabungan Mudharabah, yaitu penempatan dana dalam bentuk tabungan dengan sistem bagi hasil (mudharabah). Bank selaku pengelola dana nasabah (mudhorib) akan mengelola dana tersebut dan memberikan imbalan sesuai dengan kinerja dan porsi bagi hasil (nisbah) yang telah diperjanjikan.

2) Tabungan Wadiah merupakan penempatan dana dalam bentuk tabungan dengan prinsip titipan (wadiah). Bank boleh memberikan imbalan bersifat bonus, karena tidak diperjanjikan dan bukan suatu kewajiban.

3) Deposito Mudharabah. Deposito adalah simpanan pihak ketiga yang diamanahkan kepada bank yang penarikanya dilakukan pada waktu tertentu sesuai yang diperjanjikan. Deposito dicairkan setelah jangka waktu berakhir dan dapat diperpanjang secara otomatis. 


\section{Jasa Perbankan Syariah}

Jasa bank adalah semua aktivitas yang dilakukan oleh bank secara langsung atau tidak langsung tidak terkait tugas dan fugsinya sebagai lembaga intermediasi. Bank Syariah ikut memperlancar transaksi perdagangan dan peredaran uang dengan memberikan jaminan kepada nasabah, bertindak sebagai agen, serta memberikan beberapa layanan lain, termasuk yang berbasis teknologi informasi.

\section{Standar Layanan Perbankan Syariah}

Perbankan Syariah merupakan industri keuangan yang harus mampu menjalankan amanah secara profesional serta memiliki frontliners dan bankir dengan keterampilan layanan yang dapat memperkuat citra bisnis berbasis syariah yang menjadi difirensiasinya hal itu sangat penting guna memperoleh ridho Allah SWT. Memenuhi kebutuhan nasabah, menyikapi prilaku pesaing, serta memenuhi ekspektasi masyarakat yang tinggi terhadap peran dan keberadaan Bank Syariah.

Layanan yang dilakukan harus berlandaskan etika dan bertujuan ibadah dengan niat untuk mendapatkan ridho allah SWT siapa yang datang akan di layani secara baik, bisa memberikan solusi, harus menimbulkan rasa aman dan nyaman, menguntungkan nasabah dan Bank, serta senantiasa memberikan layanan yang terbaik secara konsisten dengan mengacu pada service level (level pelayanan) dan standrt opereting procedure (prosedur standar operasional) aspek layanan ini memerlukan operastional excellence yang menghendaki adanya standar proses guna membentuk service level yang berpengaruh terhadap standar hasil yang akan dicapai.

\section{Hipotesis}

Hipotesis merupakan jawaban sementara terhadap rumusan masalah penelitian. Dikatakan sementara karena jawaban yang diberikan baru didasarkan pada teori yang relevan tetapi memungkinkan untuk diuji dalam kenyataan empiris. Hipotesis mengemukakan pernyataan tentang harapan peneliti mengenai hubungan-hubungan antar variabel di dalam persoalan. Adapun hipotesis dalam penelitian ini yaitu:

H0: Persepsi Karyawan tentang Bank Syariah, Prinsip-Prinsip Dasar Operasional Bank Syariah, Latar Belakang Pengetahuan Agama, Pelatihan tidak memiliki pengaruh positif dan signifikan terhadap pengetahuan karyawan tentang produk-produk Bank Syariah.

H1: Persepsi Karyawan tentang Bank Syariah berpengaruh positif dan signifikan terhadap pengetahuan karyawan tentang produk-produk Bank Syariah. 
H2: Prinsip-Prinsip Dasar Operasional Bank Syariah berpengaruh secara positif dan signifikan terhadap pengetahuan karyawan tentang produkproduk Bank Syariah.

H3: Latar Belakang Pengetahuan Agama berpengaruh secara positif dan signifikan terhadap pengetahuan karyawan tentang produk-produk Bank Syariah.

H4: Pelatihan berpengaruh secara positif dan signifikan terhadap pengetahuan karyawan tentang produk-produk Bank Syariah.

H5: Persepsi Karyawan tentang Bank Syariah, Prinsip-Prinsip Dasar Operasional Bank Syariah, Latar Belakang Pengetahuan Agama, Pelatihan memiliki pengaruh positif dan signifikan terhadap produk produk Bank Syariah.

\section{Metode Pengolahan Analisis Data}

Analisis data menggunakan model regresi linear berganda (multiple regression analysis). Model ini menguji kedua variabel dependen, baik secara individual (partial) maupun secara keseluruhan (simultan), terhadap variabel independen menggunakan SPSS 21.0.

\section{Variabel Dependen: Pengetahuan karyawan tentang Produk-Produk Bank Syariah}

Menurut Gloet dan Terziovski (2004), dalam Harun, dkk (2015), definisi dari istilah pengetahuan bervariasi, pengetahuan adalah berbagai gejala yang ditemui dan diperoleh manusia melalui pengamatan akal, pengetahuan muncul ketika seseorang menggunakan akal budinya untuk mengenali benda atau kejadian tertentu yang belum pernah dilihat atau dirasakan sebelumnya.

\section{Variabel Independen}

\section{Persepsi Karyawan Terhadap Bank Syariah}

Persepsi karyawan terhadap bank syariah merupakan persepsi karyawan terhadap Bank Syariah dalam perusahaan memandang perusahaan itu sebagai tempat yang hebat untuk bekerja (kondisi kerja yang menguntungkan, tugas pekerjaan yang menarik, upah yang baik, manajemen yang bijaksana dan bertanggung jawab), tetapi seperti kebanyakan kita tahu, sangatlah tidak biasa untuk mendapatkan kesepakatan seperti itu.

\section{Prinsip-Prinsip Dasar Operasional Bank Syariah}

Prinsip adalah suatu pernyataan fundemental atau kebenaran umum maupun individual yang dijadikan para karyawan bank syariah terhadap prinsip-prinsip operasional bank syariah. sebagai sebuah pedoman untuk 
berpikir atau bertindak dan seperangkat teori dan ide-ide yang berkaitan dengan pemahamanya

\section{Latar Belakang Agama}

Islam menyangkut lima hal yakni: aqidah, ibadah, amal, ahlak (Ihsan) dan pengetahuan. Aqidah menyangkut keyakinan pada Allah, Malaikat, Rasul dan seterusnya Ibadah menyangkut pelaksanaan hubungan antara manusia dengan Allah. Amal menyangkut pelaksanaan hubungan manusia dengan sesama mahluk. Akhlak merujuk pada spontanitas tanggapan atau perilaku seseorang atau rangsangan yang hadir padanya, sementara Ihsan merujuk pada situasi di mana seseorang merasa sangat dekat dengan Allah SWT. Ihsan merupakan bagian dari akhlak. Bila akhlak positif seseorang mencapai tingkatan yang optimal, maka ia memperoleh berbagai pengalaman dan penghayatan keagamaan, itulah Ihsan dan merupakan akhlak tingkat tinggi. Selain keempat hal di atas, hal penting yang harus diketahui dalam religiusitas adalah pengetahuan keagamaan seseorang.

\section{Pelatihan}

Pelatihan yang efektif secara signifikan sangat berpengaruh terhadap peningkatan etos kerja, hal ini disebabkan karena kesalahan dan kekurangan dalam melaksanakan pekerjaan di masa silam dapat dikoreksi. Untuk memperbaiki kemampuan kinerja karyawan dan mengoreksi kekurangnya di masa silam, dapat dilakukan dengan cara meningkatkan pengetahuan dan keterampilan operasional, dalam melaksanakan suatu pekerjaan (Soeprihatin:1988:85) dalam Putri (2012:14).

\section{Metode Pengolahan Data}

Pengolahan data menggunakan statistik deskriptif dengan persamaan Uji Regresi Linear Berganda untuk menguji hipotesis dengan persamaan berikut:

\section{$Y=\alpha+\beta 1$ persepsi $+\beta 2$ prinsip-prinsip dasar + $\beta 13$ latar belakang agama $+\beta 4$ pelatihan $+\varepsilon$}

Dimana:

$\mathrm{Y}=$ Variabel pengetahuan karyawan tentang produk-produk bank syariah

$\alpha=$ Konstanta

$\beta 1=$ Variabel persepsi

$\beta 2=$ Variabel prinsip-prinsip dasar

$\beta 3=$ Variabel latar belakang pengetahuan agama

$\beta 4=$ Variabel prinsip-prinsip dasar

$\varepsilon=$ error 
Uji Statistik yang dilakukan meliputi Uji Normalitas, Uji Multikolinearitas, Uji Autokorelasi, Uji Heteroskedastisitas, Uji Hipotesis, Uji Statistik T dan Uji Signifikasi Simultan (Uji F).

\section{Hasil dan Pembahasan}

Dilihat dari 38 sampel penelitian, diketahui ukuran pemusatan variabel persepsi range: 11 , nilai minimum: 13 , nilai maksimum: 24 , nilai rata-rata: 20 , 37 , sedangkan untuk nilai ukuran penyebaran yang terdiri dari standar deviasi: 2,725 , dan nilai varian: 7,428. variabel prinsip-prinsip dasar range: 10 , nilai minimum: 20 , nilai maksimum: 30 , nilai rata-rata: 23,92 , sedangkan untuk nilai ukuran penyebaran yang terdiri dari standar deviasi: 2,665, dan nilai varian: 7,10 variabel latar belakang pengetahuan agama range: 7 , nilai minimum: 13 , nilai maksimum: 20 , nilai rata-rata: 16,45 , sedangkan untuk nilai ukuran penyebaran yang terdiri dari standar deviasi: 1, 719, dan nilai varian: 2,957variabel pelatihan range: 11 , nilai minimum: 19 , nilai maksimum: 30 , nilai rata-rata: 23,55 , sedangkan untuk nilai ukuran penyebaran yang terdiri dari standar deviasi: 2,884, dan nilai varian: 8, 200variabel produk-produk range: 13 , nilai minimum: 17 ,nilai maksimum: 30 , nilai rata-rata: 23,24 , sedangkan untuk nilai ukuran penyebaran yang terdiri dari standar deviasi: 3,157 , dan nilai varian: 9,969.

Pada uji normalitas, dapat disimpulkan bahwa data penelitian berdistribusi normal, yang ditandai dengan bentuk kurva yang memiliki kemiringan seimbang pada sisi kiri dan kanan. Uji Autokorelasi Durbin watson hitung mendekati angka 2. Durbin Watson hitung adalah 2,132, mendekati angka 2, maka dapat disimpulkan pada analisis regresi penelitian ini tidak terdapat autokorelasi.

Uji multikolinearitas menghasilkan nilai VIF untuk variabel X1, X2, X3, dan $X 4$, dengan nilai yang sama besarnya dibawah 10 . Pada variabel $X 1=1,292, X 2$ $=1,881, \mathrm{X} 3=1,965 \mathrm{X} 4=1,754$ Nilai ini berarti kurang dari sepuluh. Hal ini menunjukkan bahwa tidak terjadi multikolinearitas yang tinggi antar variable bebas dalam persamaan regresi yang diperoleh. Uji heteroskedastisitas menunjukkan bahwa titik-titik tidak membentuk pola khusus, atau data bersifat homogen.

Hasil dari analisis data secara garis besar adalah: diketahui nilai konstanta adalah -2,989. Artinya, ketika tidak ada tambahan dari persepsi, prinsip-prinsip dasar, latar belakang pengetahuan, pelatihan adalah -2,989. Apabila adanya tambahan sebesar satu satuan dari variabel persepsi, maka mempengaruhi pengetahuan karyawan tentang produk-produk perbankan syariah bertambah sebesar 0,178. Apabila ada tambahan sebesar satu satuan dari variabel prinsipprinsip dasar maka mempengaruhi pengetahuan karyawan tentang produkproduk perbankan bertambah sebesar 0,340. Apabila adanya tambahan sebesar satu satuan dari variabel latar belakang pengetahuan agama, maka 
mempengaruhi pengetahuan karyawan tentang produk-produk perbankan syariah bertambah sebesar 0,148. Apabila ada tambahan sebesar satu satuan dari variabel pelatihan maka mempengaruhi pengetahuan karyawan tentang produk-produk perbankan bertambah sebesar 0,510.

1. Uji t pada tabel menunjukan thitung adalah 1,233 dengan $p$-value 0,226 sedangkan nilai $t$ tabel sebesar 1,684 ini berarti $1,233<0,05$ maka tidak signifikan dengan nilai t hitung lebih kecil dari pada t tabel $=1,233<1,684$ dengan demikian dapat disimpulkan bawa variabel X1 pada level 95\% $(\alpha=5 \%)$, maka H0 diterima Ha ditolak, hasil uji individu ini membuktikan secara parsial tidak ada hubungan atau pengaruh positif secara individu Variabel persepsi dengan pengetahuan karyawan tentang Produk-produk bank.

2. Pengujian koefisien regresi Variabel Prinsip-Prinsip Dasar dengan Uji t pada tabel menunjukan $t$ hitung adalah 1,909 dengan $p$-value 0,065 sedangkan nilai t table sebesar 1,684 ini berarti 1,909>0,05 maka signifikan dengan nilai t hitung lebih besar dari pada t tabel. $=1,909$ $>1,684$ dengan demikian dapat disimpulkan bahwa Variabel X2 pada level 95\% ( $\alpha=5 \%)$, maka H0 ditolak Ha diterima, hasil uji individu ini membuktikan secara parsial ada hubungan atau pengaruh positif secara individu Variabel Prinsip-Prinsip Dasar dengan pengetahuan karyawan tentang produk- produk bank.

3. Pengujian koefisien regresi Varibel Latar Belakang pengetahuan agama dengan Uji $t$ pada tabel menunjukan $t$ hitung adalah 0,524 dengan p-value 0,604 sedangkan nilai t tabel sebesar 1,684 ini berarti $0,524<0,05$ maka tidak signifikan dengan nilai t hitung lebih kecil dari pada $\mathrm{t}$ tabel $=0,524<1,684$ dengan demikian dapat disimpulkan bawa variabel X3 pada level 95\% ( $\alpha=5 \%)$, maka H0 diterima Ha ditolak, hasil uji individu ini membuktikan secara parsial tidak ada hubungan atau pengaruh positif secara individu Variabel Pengetahuan Latar Belakang Agama dengan pengetahuan karyawan tentang Produk-produk bank.

4. Pengujian koefisien regresi Variabel Pelatihan dengan Uji t pada table menunjukan t hitung adalah 3,184 denga p-value 0,003 sedangkan nilai t tabel sebesar 1,684 ini berarti 3,184 >0,05 maka signifikan dengan nilai $t$ hitung lebih besar dari pada $t$ tabel. $=3,184>1,684$ dengan demikian dapat disimpulkan bahwa Variabel X4 pada level 95\% $(\alpha=5 \%)$, maka H0 ditolak Ha diterima, hasil uji individu ini membuktikan secara parsial ada hubungan atau pengaruh positif secara individu Variabel Pelatihan dengan pengetahuan karyawan tentang produk- produk bank.

Uji $\mathrm{F}$ menunjukkan apakah variabel independen yang dimasukkan dalam model mempunyai pengaruh terhadap variabel dependen. 
perhitungan $\mathrm{F}$ test yang menunjukkan nilai: 12,503 dengan tingkat probabilitas 0,000 yang jauh dibawah alpha 5\% . Hal ini berarti bahwa Fhitung $>$ Ftabel . Dengan nilai koefisien determinasi $\left(\mathrm{R}^{2}\right)$ adalah 0,602 , yang artinya bahwa variabel-variabel independen yaitu variabel Persepsi, prinsip-prinsip dasar, latar belakang pengetahuan agama, dan pelatihan mempengaruhi pengetahuan karyawan tentang produk-produk perbankan syariah variabel dependen (Y) yaitu variabel 60,2\% sedangkan 39,8\% dipengaruhi variabel lain yang tidak diteliti dalam penelitian ini.

\section{Kesimpulan}

Secara keseluruhan, penelitian ini menunjukkan bahwa variabel persepsi, prinsip-prinsip dasar, latar belakang pengetahuan agama, pelatihan jika dilakukan bersamaan, berpengaruh positif terhadap kinerja karyawan 